\title{
Role of CFTR in oxidative stress and suicidal death of renal cells during cisplatin-induced nephrotoxicity
}

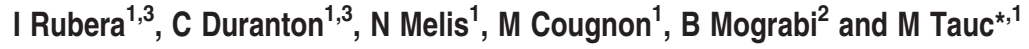

The clinical use of the antineoplastic drug cisplatin is limited by its deleterious nephrotoxic side effect. Cisplatin-induced nephrotoxicity is associated with an increase in oxidative stress, leading ultimately to renal cell death and irreversible kidney dysfunction. Oxidative stress could be modified by the cystic fibrosis transmembrane conductance regulator protein (CFTR), a $\mathrm{Cl}^{-}$channel not only involved in chloride secretion but as well in glutathione (GSH) transport. Thus, we tested whether the inhibition of CFTR could protect against cisplatin-induced nephrotoxicity. Using a renal proximal cell line, we show that the

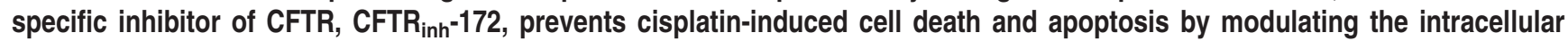
reactive oxygen species balance and the intracellular GSH concentration. This CFTR $_{\text {inh }}$-172-mediated protective effect occurs without affecting cellular cisplatin uptake or the formation of platinum-DNA adducts. The protective effect of CFTR $_{\text {inh }}{ }^{-172}$ in cisplatin-induced nephrotoxicity was also investigated in a rat model. Five days after receiving a single cisplatin injection $(5 \mathrm{mg} / \mathrm{kg})$, rats exhibited renal failure, as evidenced by the alteration of biochemical and functional parameters. Pretreatment of rats with $\mathrm{CFTR}_{\mathrm{inh}}-172(1 \mathrm{mg} / \mathrm{kg})$ prior to cisplatin injection significantly prevented these deleterious cisplatin-induced nephrotoxic effects. Finally, we demonstrate that CFTR $_{\text {inh }}-172$ does not impair cisplatin-induced cell death in the cisplatinsensitive A549 cancer cell line. In conclusion, the use of a specific inhibitor of CFTR may represent a novel therapeutic approach in the prevention of nephrotoxic side effects during cisplatin treatment without affecting its antitumor efficacy.

Cell Death and Disease (2013) 4, e817; doi:10.1038/cddis.2013.355; published online 3 October 2013

Subject Category: Cancer

Cisplatin (cis-diamminedichloroplatinum II, CisPt) is one of the most widely used and most potent chemotherapeutic agents, with antineoplastic activity against various human solid tumors. ${ }^{1}$ However, renal toxicity, which is cumulative, is a major side effect that limits the clinical use and efficacy of cisplatin in cancer therapy. ${ }^{2}$ Despite preventive strategies, such as saline hydration and diuresis, the risk of nephrotoxicity is high and occurs in approximately $20-30 \%$ of patients treated with cisplatin. ${ }^{3,4}$ Clinically, cisplatin-induced acute nephrotoxicity in humans is characterized by a low glomerular filtration rate (GFR), tubular dysfunction and renal damage. ${ }^{2}$ The pathogenesis of cisplatin-induced nephrotoxicity is complex and several mechanisms have been proposed to explain the cytotoxic effects of this drug in renal tubular cells. Cisplatin accumulates in renal tubular cells, particularly in proximal tubular cells, via two different membrane transporters: a copper transporter, Ctr1, and the organic cation transporter OCT2. Both transporters have been implicated in cisplatin uptake and cytotoxicity in vitro ${ }^{5,6}$ and in vivo. ${ }^{7}$ Once inside the cells, cisplatin undergoes aquation and interacts with cellular components, such as DNA, inducing intrastrand and interstrand cross-linking. ${ }^{1}$ Cisplatin causes tubular cell death by either apoptosis or necrosis, depending on the concentration and the exposure duration. ${ }^{8}$ Numerous studies have described the different pathways implicated in cisplatininduced apoptosis; ${ }^{3,9}$ among these pathways, mitochondrial dysfunction and oxidative stress appear to be important events in the induction of cisplatin toxicity. ${ }^{10} \mathrm{Cisplatin}$-induced acute renal failure is associated with the generation of reactive oxygen species (ROS), lipid peroxidation and a decrease in antioxidant buffering systems, such as GSH. ${ }^{10-12}$

In recent years, an impressive list of renoprotective approaches has been reported that have targeted pathways involved in cisplatin-induced renal cell death. ${ }^{3,13}$ However, most of these studies have not tested whether those renoprotective strategies compromised the chemotherapeutic efficacy of cisplatin. Therefore, the identification of novel therapeutic interventions to prevent cisplatin-induced nephrotoxicity without inhibiting its antineoplastic efficacy is of particular clinical interest in cancer therapy.

Cystic fibrosis transmembrane conductance regulator (CFTR), loss of function mutations of which cause the autosomal recessive lethal disease cystic fibrosis, is expressed in a variety of epithelial cells, including cells of all nephron segments. ${ }^{14}$ CFTR is not only a cAMP-dependent chloride channel but also a modulator of other ion channels

\footnotetext{
${ }^{1}$ University of Nice-Sophia Antipolis, LP2M CNRS-3472, Laboratories of Excellence, Ion Channel Science and Therapeutics, Parc Valrose, Nice 06108, France and 'University of Nice-Sophia Antipolis, IRCAN, CNRS 7284, INSERM U 1081, 28 avenue de Valombrose, Nice 06107, France

*Corresponding author: M Tauc, LP2M CNRS-3472, Faculté des Sciences, Parc Valrose, 06108 Nice, Nice 06108 , France. Tel: +33 492076894 ; Fax: +33 4920768 50; E-mail: tauc@unice.fr

${ }^{3}$ These authors contributed equally to this work.

Keywords: apoptosis; cancer; kidney injury; CFTRinh-172; GSH; NGAL

Abbreviations: CFTR, cystic fibrosis transmembrane conductance regulator; GSH, glutathione; ROS, reactive oxygen species; MDA, malondialdehyde; GFR, glomerular filtration rate; BUN, blood urea nitrogen; NGAL, neutrophil gelatinase-associated lipocalin; NAG, $N$-acetyl- $\beta$-D-glucosaminidase

Received 20.5.13; revised 16.7.13; accepted 06.8.13; Edited by Y Shi
} 
and transporters. ${ }^{15}$ At the cellular level, we have previously reported that CFTR is involved in the transport of GSH and thus modulates ROS levels and apoptosis in renal proximal cells. ${ }^{16-18}$

In the present report, we show that $\mathrm{CFTR}_{\text {inh }}-172$ (a highly selective inhibitor of $\mathrm{CFTR}^{19}$ ) protects renal cells and kidney function from cisplatin-induced injury. CFTR may thus represent a key target for the design of novel renoprotective strategies during cancer therapy.

\section{Results}

CFTR $_{\text {inh }}-172$ reduces cisplatin-induced cell death in renal proximal cells by modulating oxidative stress. Confluent kidney proximal cell cultures (PCT cells ${ }^{18}$ ) were exposed to increasing concentrations of cisplatin (varying from 1.9 to $50 \mu \mathrm{g} / \mathrm{ml}$ ), and cell viability/cytotoxicity was determined after $24 \mathrm{~h}$ using fluorescent labeling (LIVE/ DEAD assay kit). Figure 1a illustrates the effect of cisplatin (12.5 and $25 \mu \mathrm{g} / \mathrm{ml}$ ) on confluent cell monolayers in the absence (upper part) and presence (lower part) of the highly selective inhibitor of CFTR, CFTR inh $^{-172}(5 \mu \mathrm{M})$. Cisplatininduced cell death in a dose-dependent manner (lower levels of green labeling areas), as revealed by the micrographs shown in Figure 1a. By contrast, cells co-incubated with cisplatin and CFTR inh $^{-172}$ exhibited significantly higher levels of green fluorescence areas compared with cells exposed to cisplatin alone, indicating a greater number of living cells. The dose-dependent toxic effect of cisplatin was quantified, and the results are illustrated in Figure $1 \mathrm{~b}$. The addition of CFTR inh $^{-172}(5 \mu \mathrm{M})$ protected the cells from cisplatin toxicity for all of the concentrations of cisplatin that were tested. Decreasing the intracellular GSH content with the glutathione synthase inhibitor (DL-Buthionine-[S,R]-sulfoximine, BSO, $0.5 \mathrm{mM}$ ) dramatically enhanced the cisplatin toxicity (even at low doses of cisplatin, Figure 1b). In the subsequent experiments, a concentration of $12.5 \mu \mathrm{g} / \mathrm{ml}$ cisplatin was used. In contrast to BSO, the addition of $\alpha$-tocopherol (an organic antioxidant, $30 \mu \mathrm{M}$, Figure 1c) prevented cisplatin-induced cell death. These data suggest that cisplatin-induced cell death is largely mediated through an increase in the level of oxidative stress and that the inhibition of CFTR by CFTR $_{\text {inh }}-172$ prevents the toxic effects of cisplatin in renal cells (Figures $1 \mathrm{~b}$ and c). CFTR $_{\text {inh }}-172$, BSO, $\alpha$-tocopherol and vehicle (control: DMSO, $0.025 \%$ ) did not have any effect in the absence of cisplatin (Figure 1c).
To quantify apoptotic cell death upon cisplatin exposure, the caspase-3 activity was measured. Exposing PCT cells to cisplatin $(12.5 \mu \mathrm{g} / \mathrm{ml})$ induced a time-dependent activation of caspase-3 activity (Figure 1d) that reached a maximum after $24 \mathrm{~h}$ of incubation (an approximately sevenfold increase, Figure 1d). Interestingly, the addition of CFTR $_{\text {inh }}-172(5 \mu \mathrm{M})$ significantly blunted by $30 \%$ the stimulation of caspase-3 activity following cisplatin exposure (Figure 1e). Incubating cells with $\alpha$-tocopherol $(30 \mu \mathrm{M})$ prevented the increase of cisplatin-induced caspase-3 activity. By contrast, BSO exposure $(0.5 \mathrm{mM})$ enhanced the effect of cisplatin on caspase-3 activity. CFTR inh -172 , BSO, $\alpha$-tocopherol alone had no effect on the basal caspase-3 activity.

We also examined the effect of CFTR inh -172 on caspase-3 activation in a cell line devoid of endogenous CFTR expression and exposed to cisplatin $(12.5 \mu \mathrm{g} / \mathrm{ml})$. These cells (fibroblasts PS120, ${ }^{20}$ ) clearly exhibited caspase-3 activation upon cisplatin exposure but remained insensitive to CFTR $_{\text {inh- }}$ 172 (Figure 1f), confirming the specificity of the inhibitor. As expected, the antioxidant $\alpha$-tocopherol $(30 \mu \mathrm{M})$ reduced cisplatin-induced caspase-3 activation.

Because the data suggested a link between CFTR activity, cisplatin-induced cell death and oxidative stress, the intracellular levels of reduced glutathione (GSH) and the ROS levels were determined. Cisplatin treatment $(12 \mathrm{~h})$ decreased the intracellular GSH level by $30 \%$; an effect almost completely prevented by co-incubation in the presence of CFTR $_{\text {inh }}-172(5 \mu \mathrm{M}$, Figure 2a). As expected, when BSO was used as a positive control, it induced a dramatic decrease in the GSH level. In another series of experiments, we recorded the increasing rate of ROS levels in cells acutely exposed to cisplatin. The ROS level increased rapidly following cisplatin addition. CFTR $_{\text {inh }}-172$ partially prevented this increase, maintaining a ROS concentration close to the control value (Figure $2 b$ ). This result was confirmed by the measurement of the initial slope of ROS production, as shown in Figure 2c. CFTR $_{\text {inh }}-172$ alone had no effect on ROS production, whereas tBHP (tertButyl hydroperoxide), an oxidant agent used as a positive control, dramatically increased the intracellular ROS level (Figures 2b and c).

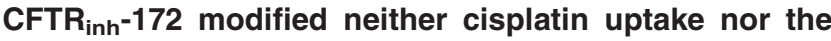
formation of platinum-DNA adducts in renal proximal cells. We also looked for a possible inhibitory effect of CFTR $_{\text {inh }}-172$ on the uptake of cisplatin into PCT cells. As illustrated in Figure $3 \mathrm{a}, \mathrm{CFTR}_{\mathrm{inh}}-172$ did not affect

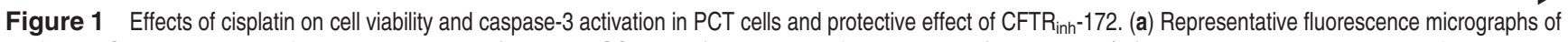
confluent PCT cells maintained for $24 \mathrm{~h}$ in the absence (control DMSO $0.025 \%$ ) or presence of cisplatin alone ( $12.5 \mathrm{or} 25 \mu \mathrm{g} / \mathrm{ml}$ ) or in the concomitant presence of cisplatin and CFTR $_{\text {inh }}-172(5 \mu \mathrm{M})$. Images were obtained in fluorescent mode at $550 \mathrm{~nm}$ for calcein-AM labeling (living cells, green fluorescence) and at $650 \mathrm{~nm}$ for propidium iodide labeling (dead cells, red fluorescence). Scale bar represents $100 \mu \mathrm{m}$. (b) Dose-response curves obtained for increasing concentrations of cisplatin (varying from 1.9 to $50 \mu \mathrm{g} / \mathrm{ml}$ ) obtained in the absence (circles) or presence of $\mathrm{CFTR}_{\text {inh }}-172(5 \mu \mathrm{M}$, squares) or BSO $(0.5 \mathrm{mM}$, triangles). The green fluorescence intensity was considered to be representative of the level of living cells. Values are expressed as the means \pm S.E.M. of the intensity of the green fluorescence $(n=3-19)$. (c) Histograms representing cell survival measured as in $\mathbf{b}$ for a single concentration of cisplatin $(12.5 \mu \mathrm{g} / \mathrm{ml})$ and after the addition of CFTR inh $^{-172, ~ B S O ~ o r ~} \alpha$-tocopherol (30 $\left.\mu \mathrm{M}\right)$. Values are expressed as the means \pm S.E.M. $\left(n=3-19,{ }^{* *} P<0.01,{ }^{* * *} P<0.001\right)$. (d) Cisplatin-induced caspase-3 activity measured at different times of incubation $(6,12$ and $24 \mathrm{~h})$ measured in PCT $(n=4)$. (e) Caspase-3 activity measured after $24 \mathrm{~h}$ of incubation with cisplatin alone $(12.5 \mu \mathrm{g} / \mathrm{ml})$ or in the concomitant presence of CFTR inh $^{-172}(5 \mu \mathrm{M}), \alpha$-tocopherol $(30 \mu \mathrm{M})$ or BSO $(0.5 \mathrm{mM})$. Control experiments were performed in the presence of CFTR-172 alone, $\alpha$-tocopherol alone or BSO alone. Values are expressed as the means \pm S.E.M. $\left(n=3-15 ;{ }^{* \star} P<0.01\right)$. (f) Cisplatin-induced caspase-3 activity in PS120 fibroblast cultures. Cells were exposed to cisplatin $(12.5 \mu \mathrm{g} / \mathrm{ml}, 24 \mathrm{~h})$ in the absence or presence of CFTR $_{\text {inh }}-172(5 \mu \mathrm{M})$ or $\alpha$-tocopherol $(30 \mu \mathrm{M})$. The histogram represents the caspase-3 activity \pm S.E.M. $\left(n=3-11 ;{ }^{* *} P<0.01\right)$
} 
intracellular platinum accumulation. Moreover, reducing the incubation temperature from 37 to $4^{\circ} \mathrm{C}$ significantly reduced the accumulation of platinum, demonstrating that the measurements of endogenous platinum reflects a real uptake and not a non-specific binding of platinum to the plasma membrane. Thus, these data exclude the possibility a
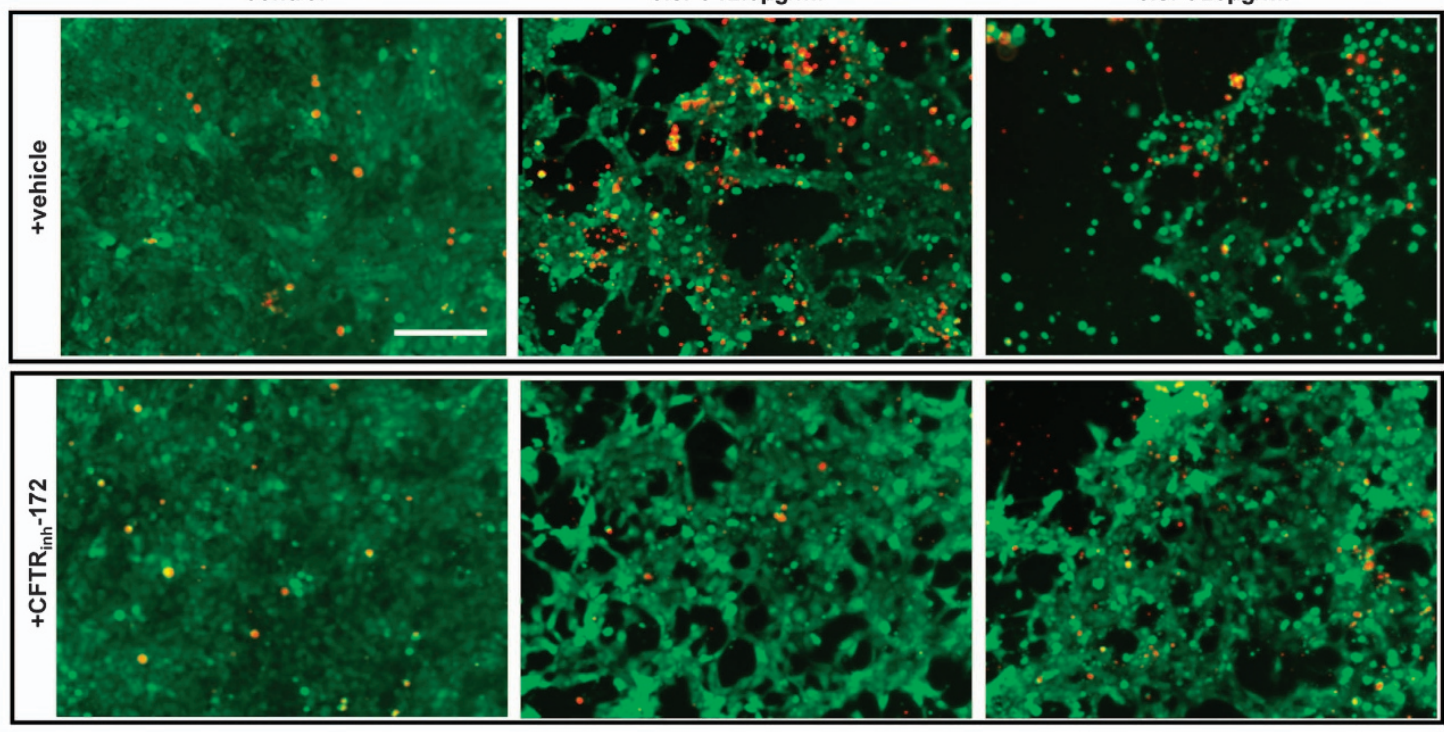

b
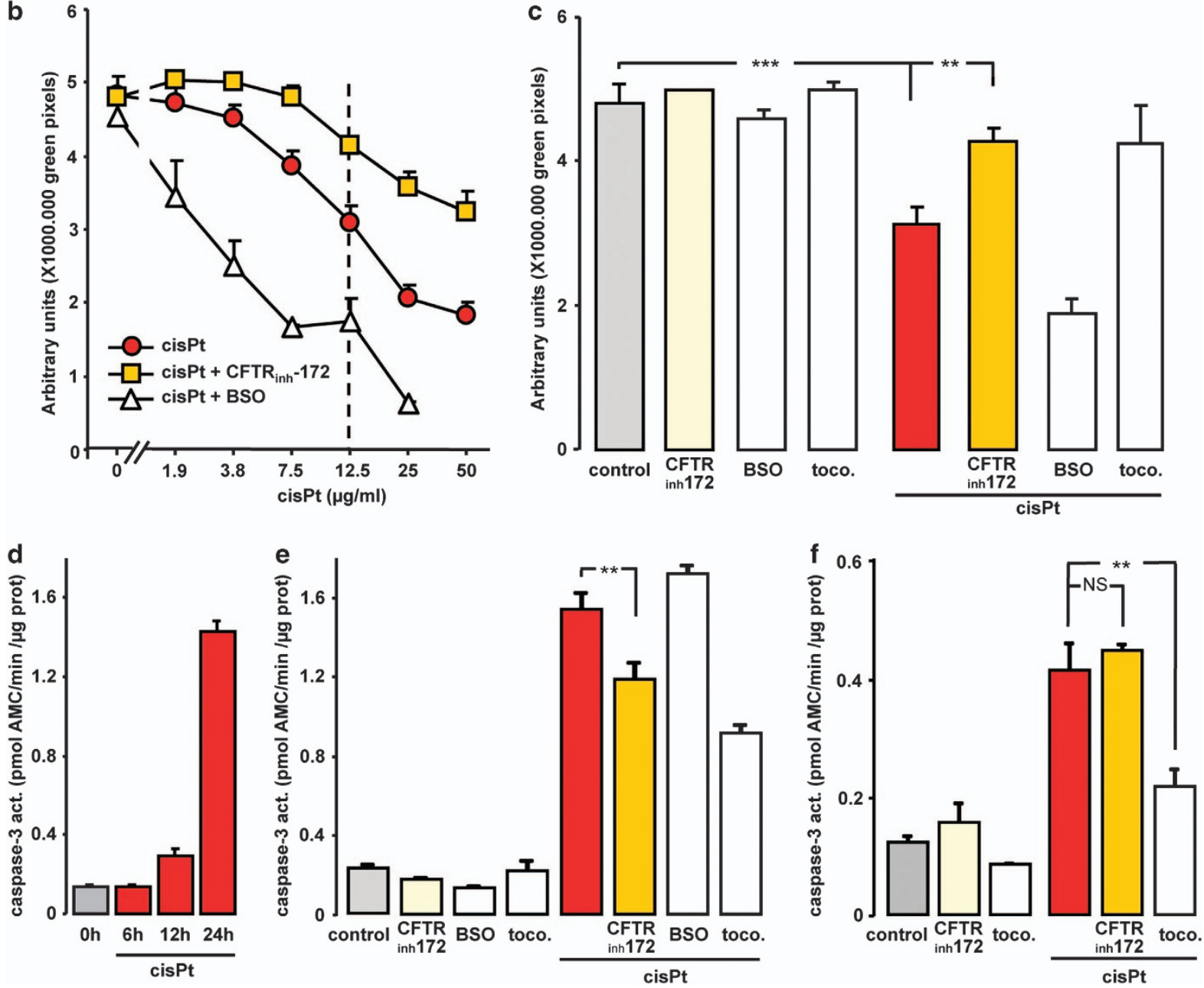

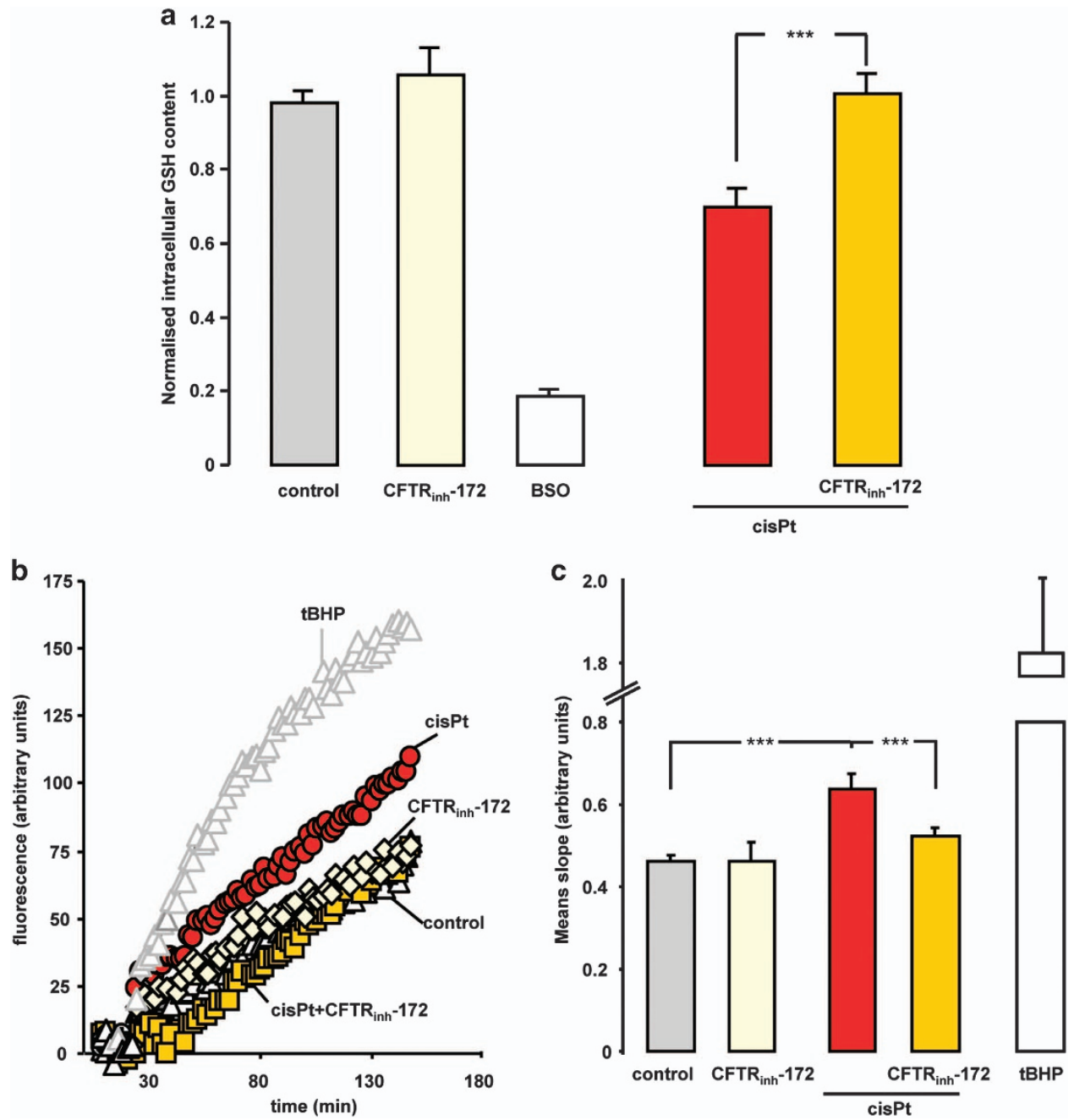

Figure 2 Effect of CFTR inh-172 on the intracellular GSH content and on ROS production during cisplatin treatments in PCT cells. (a) GSH levels were measured in PCT cells using a fluorescent assay kit containing an OPA probe. Confluent monolayers were incubated in control conditions (DMSO $0.025 \%), \mathrm{CFTR}$ inh-172 (5 $\mu \mathrm{M}), \mathrm{BSO}(0.5 \mathrm{mM})$ or cisplatin $(12.5 \mu \mathrm{M})$; or in the concomitant presence of cisplatin and CFTR inh-172. The values \pm S.E.M. $(n=5-9)$ are normalized to the GSH level measured in control DMSO condition ( ${ }^{* \star *} P<0.001$ ). (b) Kinetics of ROS production in PCT cells as a function of time. Cells were incubated for $1 \mathrm{~h}$ in the presence of carboxy-H2DCFDA ( $5 \mu \mathrm{M}$ ), washed and fluorescence was measured every $2 \mathrm{~min}$ for a control period of $20 \mathrm{~min}$ and after the addition of cisplatin ( $12.5 \mu \mathrm{M}$, circles), CFTR inh $^{-172}$ ( $5 \mu \mathrm{M}$, diamonds) or both substances together (squares). A positive control was obtained by adding $1 \mathrm{mM}$ of tBHP (grey triangles) as an external oxidant molecule. (c) Histograms representing the slope of fluorescence variations (calculated for a period of $60 \mathrm{~min}$ after the addition of the various substances) as measured in $\mathbf{b}$, corresponding to cells exposed to cisplatin, cisplatin + CFTR $_{\text {inh }}-172$ or CFTR inh $^{-172}$ alone. Values are expressed as the means \pm S.E.M. $\left(n=6 ;{ }^{* * \star} P<0.001\right)$

that the protective effect of CFTR $\mathrm{inh}-172$ is due to a reduction in cisplatin uptake by renal cells.

The antineoplastic effect of cisplatin is mainly attributed to its ability to react with DNA, resulting in intra- and interstrand crosslinking and leading, finally, to DNA damage and cell death. ${ }^{1,21}$ We therefore investigated whether CFTR inh -172 could affect the formation of cisplatin-DNA adducts. Immunostaining with a monoclonal antibody raised against Pt-(GG) intrastrand adducts in DNA was performed. Almost all cisplatin-exposed PCT cells exhibited a marked fluorescent staining of the nucleus, independent on the presence or absence of $\mathrm{CFTR}_{\mathrm{inh}}-172$ (Figures $3 \mathrm{~b}$ and $\mathrm{c}$ ). The specificity of the immunostaining against Pt-(GG) intrastrand cross-links is confirmed by the absence of any labeling in the control cells (not exposed to cisplatin). These data indicate that $\mathrm{CFTR}_{\mathrm{inh}}-172$ does not interfere with the formation of platinum-DNA adducts.
CFTR $_{\text {inh }}-172$ does not affect cisplatin-induced cell death in a cancer cell line. To determine whether the inhibition of CFTR might affect the antineoplastic activity of cisplatin, the cisplatin-sensitive human non-small-cell lung cancer (NSCLC) cell line A549 was exposed to increasing doses of cisplatin alone or in combination with CFTR inh -172 . Phasecontrast microscopy in combination with cytotoxicity fluorescent imaging (using propidium iodide ( $\mathrm{PI}$, red) and Hoechst 33258 (blue labeling), shows similar cytotoxicity of cisplatin in control- and CFTR inh $^{-172-t r e a t e d ~ A 549 ~ c e l l s ~(F i g u r e ~ 4 a) . ~}$ Consistently, there was no significant difference in the rate of cell death measured in cisplatin-treated cells in the presence or absence of CFTR inn $^{-172}$ (Figure $4 b$ ).

Because this first set of experiments suggested that CFTR $_{\text {inh }}-172$ protects renal cells from the toxic effects of cisplatin without reducing its antitumor activity, CFTR inh -172 

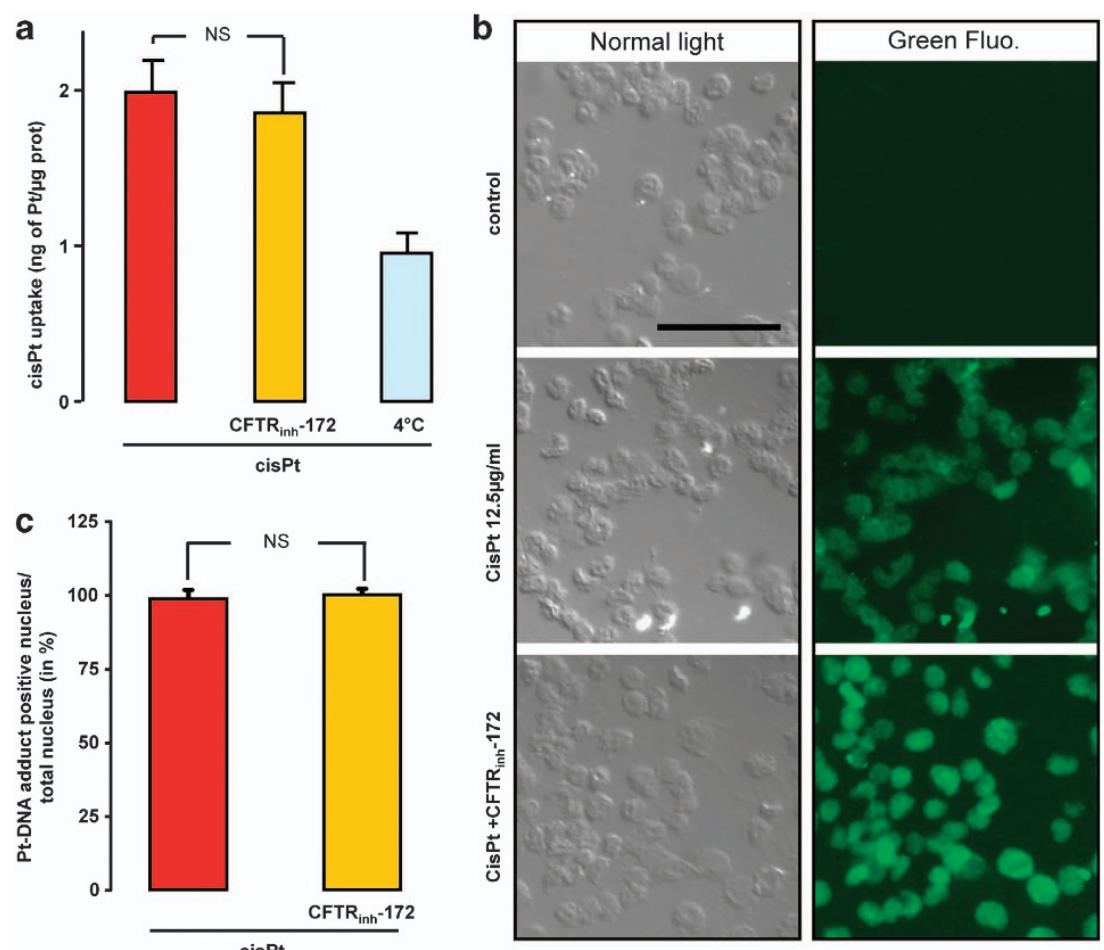

Figure 3 CFTR $_{\text {inh }}-172$ does not modify cisplatin uptake or cisplatin-DNA adduct formation in PCT cells. (a) Cisplatin uptake was measured in PCT cells using atomic absorption spectrometry (AAS). Cell cultures were exposed over $4 \mathrm{~h}$ to $25 \mu \mathrm{g} / \mathrm{ml}$ of cisplatin in the absence or presence of CFTR inh $^{-172}(5 \mu \mathrm{M})$. Values are expressed as the means \pm S.E.M. $(n=9)$. (b) Visualization of Pt-DNA adducts: Normarsky micrographs and immunofluorescence staining of Pt-(GG) adducts obtained in PCT cells. The cells were exposed to cisplatin $(12.5 \mu \mathrm{g} / \mathrm{ml})$ for $4 \mathrm{~h}$ in the absence or presence of $\mathrm{CFTR}_{\text {inh }}-172(5 \mu \mathrm{M})$ and then cultured for $20 \mathrm{~h}$ before immunostaining was performed. The Normarsky and fluorescent micrographs represent the same field of the slide. The negative control condition was performed by culturing the cells for $24 \mathrm{~h}$ in the absence of cisplatin. (c) Ratio of nuclei positive for Pt-DNA to total nuclei in the same field. Values are expressed as the means \pm S.E.M. $(n=3)$

was investigated for its protective effects on cisplatin-induced nephrotoxicity in an experimental rat model.

CFTR $_{\text {inh }}-172$ protects renal function in cisplatin-induced nephrotoxicity by reducing cisplatin-induced renal oxidative stress. To estimate cisplatin-induced renal dysfunction in a rat model, we first assessed blood nephrotoxic biomarkers such as serum creatinine and BUN (blood urea nitrogen) 5 days after a single injection of cisplatin $(5 \mathrm{mg} / \mathrm{kg}$, intraperitoneal (i.p.)). The cisplatin injection increased serum creatinine and BUN levels. In contrast, these cisplatin-induced alterations were significantly reduced by $\mathrm{CFTR}_{\text {inh }}-172$ pretreatment $(1 \mathrm{mg} / \mathrm{kg}$, i.p., prior to the cisplatin injection, Figures $5 \mathrm{a}$ and b). $\mathrm{N}$-acetyl$\beta$-D-glucosaminidase (NAG), a classical biomarker of tubular injury ${ }^{22}$ and neutrophil gelatinase-associated lipocalin (NGAL), an early biomarker of renal failure, ${ }^{23}$ were also measured. Comparisons of NAG and NGAL concentrations between urine samples collected by spontaneous voiding before cisplatin injection and 5 days later clearly showed that cisplatin induced a significant increase of both biomarkers (Figures $5 \mathrm{c}$ and d). Those increases were

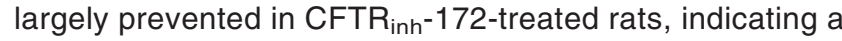
protection against cisplatin-induced tubular injury. Treatment with $\mathrm{CFTR}_{\mathrm{inh}}-172$ alone altered neither plasma biomarkers nor urinary NAG and NGAL concentrations (Figures 5a-d).
Renal function was also estimated by measurements of (i) GFR, (ii) the fractional excretions of sodium and glucose (markers of proximal tubular dysfunction) and (iii) urine osmolality. Five days after the cisplatin injection, renal failure was observed in the cisplatin-treated group, as evidenced by a dramatic decrease in GFR (Figure 6a) together with a dramatic increase in the fractional excretion of sodium (Figure $6 \mathrm{~b}$ ) and glucose (Figure 6c). Additionally, a reduction in the urine osmolality was observed in cisplatin-treated rats (Figure 6d). All of these cisplatin-induced renal alterations were significantly decreased by pretreatment with $\mathrm{CFTR}_{\text {inh }}-172$ (Figures 6a-d). In addition to the alteration of kidney functions, cisplatin treatment caused a significant decrease in the body weight of rats within 5 days (Table 1). CFTR inh $^{-172}$ pretreatment abrogated cisplatin-induced body weight changes without modifying the renal accumulation of platinum (Table 1).

To obtain insights into the mechanisms involved in the protective effect mediated by $\mathrm{CFTR}_{\text {inh }}-172$, oxidative stress markers, such as the total GSH content and lipid peroxidation levels were estimated in the renal tissue from the different groups of rats (Figure 7). Cisplatin treatment significantly increased renal malondialdehyde (MDA, Figure 7a) levels and decreased renal GSH content (Figure 7b). CFTR inh -172 pretreatment significantly blunted cisplatin-induced modifications of these parameters in kidney tissue. CFTR inh -172 alone did not modify the levels of MDA or GSH compared with the control group. 
a

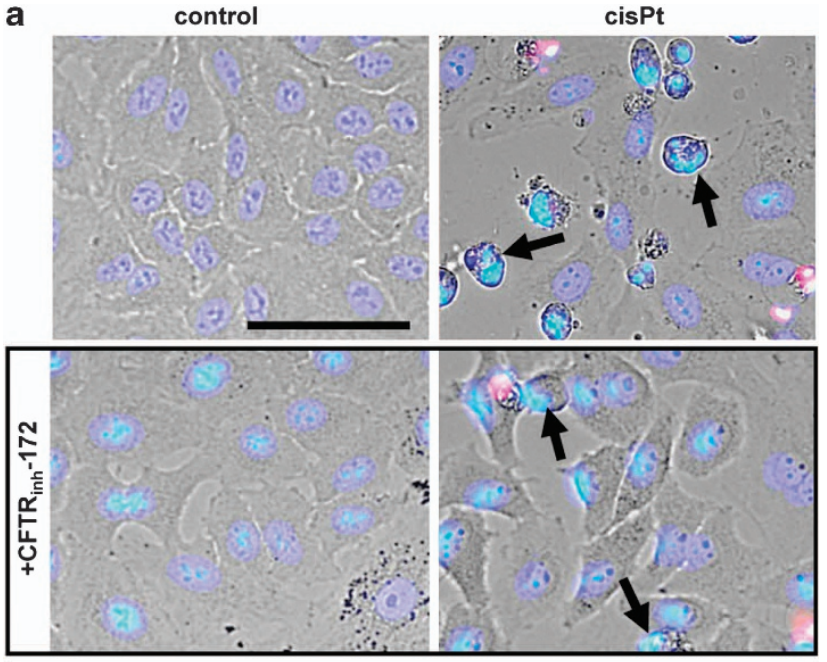

b

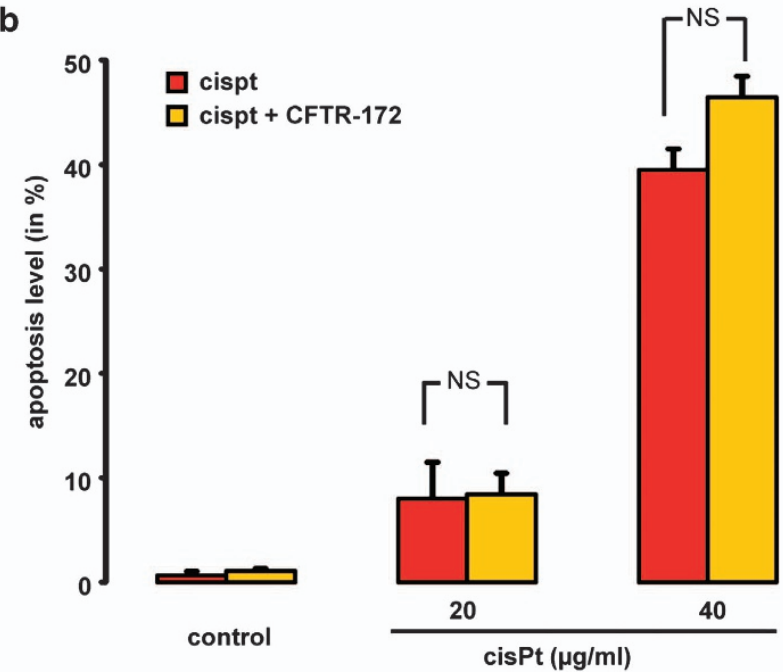

Figure 4 CFTR $_{\text {inh }}-172$ treatment does not affect the sensitivity of A549 cancer cells to the chemotherapeutic drug cisplatin. A549 cells were challenged with increasing doses of cisplatin $(\mu \mathrm{g} / \mathrm{ml})$ in the presence of CFTR inh $^{-172}(5 \mu \mathrm{M})$ for $24 \mathrm{~h}$, and the cytotoxicity was measured using propidium iodide ( $\mathrm{PI}, \mathrm{red})$ and Hoechst 33258 (blue) labeling. (a) Representative phase-contrast microscopy images (merged images of the blue (Hoechst) and red (PI) and the phase picture): the arrows indicate typical apoptotic condensed nuclei. (b) Dose-response curves (\% of apoptotic figures) of A549 cells to cisplatin in the presence of CFTR inh $^{-172}$. Values are expressed as the means \pm S.E.M. $(n=4)$

\section{Discussion}

Nephrotoxicity is a major dose-limiting factor in the clinical use of cisplatin, one of the most potent antineoplastic drugs frequently used for the treatment of various types of cancers. ${ }^{1,2}$ In addition to its therapeutic cytotoxic effect on cancer cells through its ability to bind DNA, cisplatin has been reported to induce oxidative stress, which is particularly damaging to the kidney, an organ that is highly vulnerable to the damage caused by ROS.

Our present data show that cisplatin induces cell death in a proximal cell line, an effect paralleled by marked increase of ROS, decrease of intracellular GSH content and activation of caspase-3-dependent apoptosis, observations similar to those in other renal proximal cell models. ${ }^{24-27}$ Interestingly, the blockade of CFTR by the specific inhibitor CFTR inh -172 prevented these cisplatin-induced cellular events and protected the cells from apoptotic cell death. The physiological relevance of CFTR-sensitive cell death in vivo is apparent from the effect of CFTR inh $^{-172}$ in a rat model of cisplatininduced renal failure. A single injection of cisplatin induced a renal dysfunction evidenced by the impairment of both biochemical and functional renal parameters. Pretreatment of rats with $\mathrm{CFTR}_{\text {inh }}-172$ largely prevented the deleterious effects of cisplatin on renal integrity, likely through a decrease in cisplatin-induced oxidative stress. This hypothesis is supported by our previous studies, ${ }^{16,17}$ which reported that CFTR is involved in the control of the oxidative stress levels through its ability to transport GSH (a major ROS scavenger in proximal cells) out of the cell. Our data demonstrate, for the first time, an important role for CFTR in the prevention of cisplatin-induced nephrotoxicity through the modulation of oxidative stress. Interestingly it has been recently shown ${ }^{29}$ that cimetidine was also able to inhibit cisplatin-induced ROS generation through an interaction with the heme protein of cytochrome P450. However, the protective mechanisms against cisplatin injury mediated by cimetidine or CFTRinh172 are different involving an impairment of ROS production or an enhancement of the ROS buffering capacity, respectively.

CFTR belongs to the large family of ABC transporters that are known to be involved in the extrusion of many drugs; ${ }^{28}$ thus, it was of importance to demonstrate that the inhibition of CFTR did not lead to a decrease in the intracellular concentration of cisplatin, which would provide an alternative explanation for the protective effect of $\mathrm{CFTR}_{\text {inh }}-172$. We clearly demonstrate that CFTR is not involved in cisplatin uptake and accumulation. We also show that CFTR $_{\text {inh }}-172$ does not impair the formation of antineoplastic platinum-DNA adducts. $^{1}$

Among the CFTR inhibitors, we chose to use the thiazolidinone $\mathrm{CFTR}_{\text {inh }}-172$, a potent and highly specific inhibitor of CFTR. ${ }^{19} \mathrm{CFTR}_{\text {inh }}-172$ is a useful tool for studies in animal models because its pharmacology and efficacy have already been studied in vivo in rodents. CFTR $_{\text {inh }}-172$ has a low toxicity and is mainly excreted by the kidney without major metabolism; CFTR inh -172 accumulates mainly in the liver, intestine and kidney. ${ }^{30} \mathrm{~A}$ single intraperitoneal injection (i.p.) of $\mathrm{CFTR}_{\mathrm{inh}}-172$ reduced cholera toxin-dependent intestinal fluid loss in rodent models of secretory diarrheas. ${ }^{19,31}$ Another study showed that the administration of CFTR inh -172 modifies nasal potential difference. ${ }^{32}$ Inhibition of CFTR with CFTR $_{\text {inh }}-172$ further modifies the adaptive erythroid response to hypoxia. ${ }^{16}$ Furthermore, in a rat model of duodenal ulceration, CFTR $_{\text {inh }}-172$ pretreatment $(1 \mathrm{mg} / \mathrm{kg}) 1 \mathrm{~h}$ before cysteamine injection prevented duodenal ulcer formation. ${ }^{33}$ CFTR inhibition has been described to persist several hours after i.p. injection, ${ }^{19,33}$ thus as most of the kidney damage has been reported to appear within the first hour after the administration of cisplatin, CFTR inh $^{-172}$ pretreatment (the day before and $30 \mathrm{~min}$ prior to the unique injection of cisplatin) represents a useful approach to prevent CFTR-mediated nephrotoxicity. More recently, Verkman and colleagues ${ }^{34}$ identified another class of CFTR inhibitors (benzopyrimidopyrrolo- 

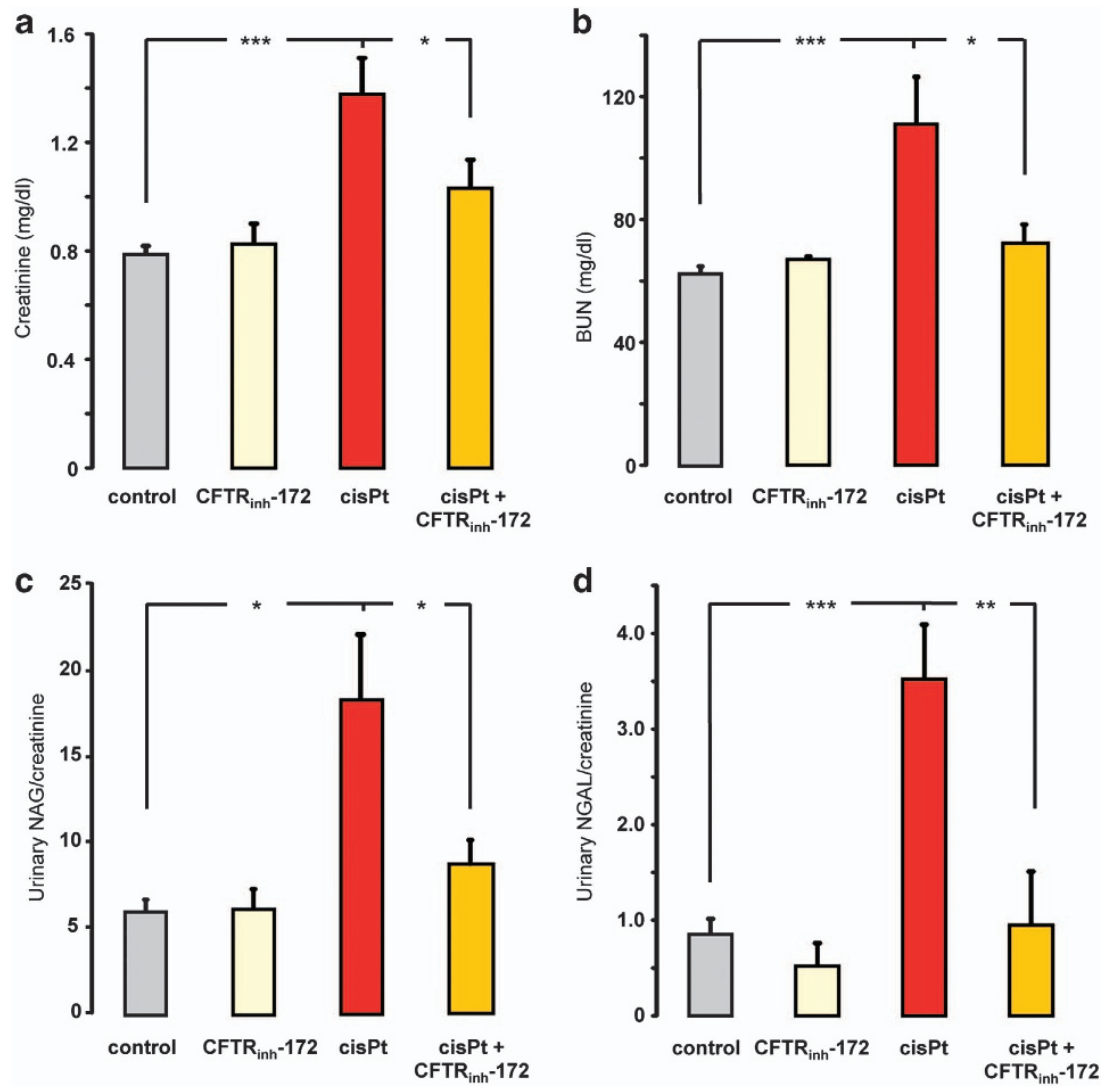

Figure 5 Protective effect of CFTR $_{\text {inn-172 }}$ against cisplatin-induced nephrotoxicity in rats. (a) Serum creatinine, (b) blood urea nitrogen (BUN), (c) urinary NAG/creatinine ratio and (d) urinary NGAL/creatinine ratio (NAG and NGAL, kidney damage biomarkers) in control $(n=10)$, CFTR inh $^{-172-t r e a t e d ~}(n=3)$, cisplatin-treated $(n=7-8)$ and cisplatin + $\mathrm{CFTR}_{\text {inh }}-172$-treated rats $(n=7-8) 5$ days after a saline or cisplatin injection $(5 \mathrm{mg} / \mathrm{kg})$. Results are expressed as the means \pm S.E.M.. ${ }^{*} P<0.05,{ }^{* \star} P<0.01,{ }^{* \star *} P<0.001$

oxazinedione, BPO) with improved potency, metabolic stability and aqueous solubility. However, BPO-27 has been demonstrated to be effective only in preventing renal cyst expansion in a polycystic kidney disease model. ${ }^{34}$ A myriad of renoprotective strategies have been used to prevent cisplatininduced nephrotoxicity in experimental models, ${ }^{3}$ such as antioxidant treatment or inhibitors of cell death pathways. However, the targeted proteins are often ubiquitous regulators of cellular signaling pathways. The advantage of a CFTR ${ }_{\text {inh }}{ }^{-}$ 172-based treatment is that it only targets CFTR-expressing cells, that is, epithelial cells, including the highly drug-sensitive kidney. This specificity is confirmed by our data demonstrating that $\mathrm{CFTR}_{\text {inh }}-172$ did not interfere with cisplatin-induced apoptosis in fibroblast cells that do not express CFTR.

Furthermore, only a few of the renoprotective strategies published have tested whether the proposed treatments compromised the chemotherapeutic efficacy of cisplatin, which could be assessed by using cancer cell lines or tumorbearing animal models $\mathrm{s}^{27,29,35,36}$ and is of particular importance, considering the therapeutic potential of cisplatin. Cisplatin is one of the principal chemotherapeutic agents used for the treatment of NSCLC, which is a frequent and aggressive form of lung cancer. We have chosen to study the effect of $\mathrm{CFTR}_{\text {inh }}-172$ on cisplatin-induced cell death in NSCLC A549 cells. Our studies clearly rule out the hypothesis that $\mathrm{CFTR}_{\mathrm{inh}}-172$ hampers the antitumor activity of cisplatin.
Collectively, these data indicate that a pharmacological inhibitor of CFTR protects renal cells and kidney function from cisplatin-induced injury without compromising the antineoplastic efficacy of cisplatin. In conclusion, targeting CFTR represents a promising and novel approach for the treatment of nephrotoxic side effects caused by cisplatin during cancer therapy.

\section{Materials and Methods}

Immortalized proximal cell line and fibroblast cultures. The characterization and culture protocol of immortalized cell lines from the murine renal proximal tubule (PCT) has been described in detail in previous studies. ${ }^{18}$ Fibroblasts from the PS120 cell line were cultured according to a previously described protocol. ${ }^{37}$ Cells were maintained in a $5 \% \mathrm{CO}_{2}$ atmosphere at $37^{\circ} \mathrm{C}$. The human NSCLC cell line A549 was purchased from the American Type Culture Collection (ATCC, Manassas, VA, USA). Cells were cultured in Dulbecco's modified Eagle's medium/F12 (DMEM/12) with penicillin $(100 \mathrm{U} / \mathrm{ml})$, streptomycin $(100 \mu \mathrm{g} / \mathrm{ml})$ and $10 \%$ fetal bovine serum (FBS).

Cell viability/cytotoxicity assay kit. The LIVE/DEAD Cell Viability/ Cytotoxicity Assay Kit (Invitrogen, Carlsbad, CA, USA) was used on PCT cells after $24 \mathrm{~h}$ of incubation. With this kit, living cells are green-labeled (detecting calcein$\mathrm{AM})$ and dead cells are red-labeled (detecting homodimeric BET). Cells were visualized with a Carl Zeiss (Gottingen, Germany) Axiover D1 inverted microscope. Quantifications of green and red levels were performed using individual pixel quantification with ImageJ software on three independent micrographs per well.

Caspase-3 activity assay. Caspase-3 activity was measured using fluorometric assays (CaspACE assay system, fluorometric, Promega, Madison, 

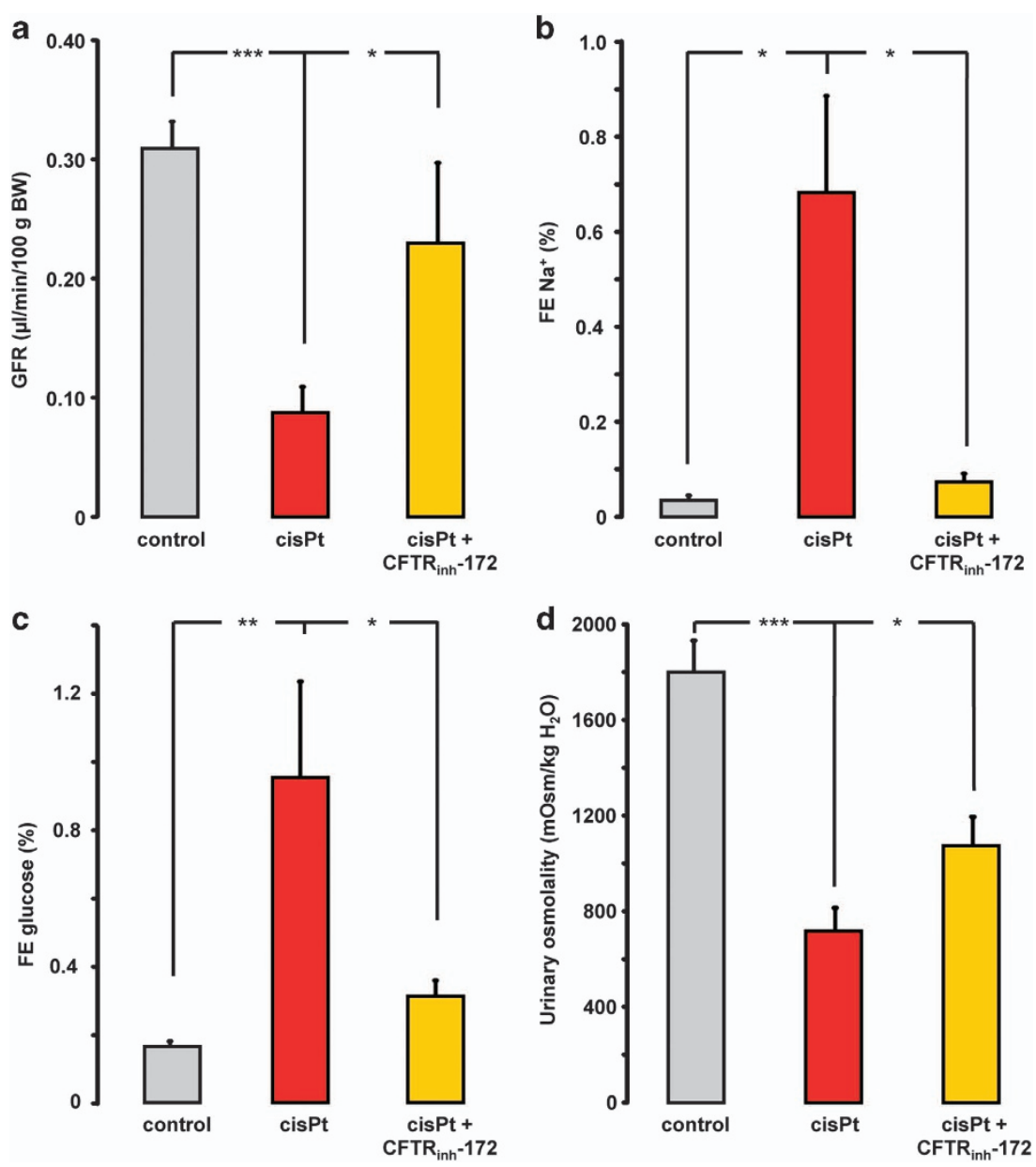

Figure 6 CFTR inh -172 improves the renal function and decreases oxidative stress in cisplatin-treated rats. Renal function was measured 5 days after a saline or cisplatin injection $(5 \mathrm{mg} / \mathrm{kg})$ in control, cisplatin-treated and cisplatin $+\mathrm{CFTR}_{\text {inh }}-172$-treated rats. (a) GFR, (b) fractional excretion (FE) of $\mathrm{Na}^{+}$, (c) FE of glucose and (d) urine osmolality. Values are expressed as the means \pm S.E.M. of $6-15$ rats per group. ${ }^{*} P<0.05,{ }^{* *} P<0.01,{ }^{* \star *} P<0.001$

Table 1 Delta body weight and platinum kidney content in control, CFTR-172 and cisplatin-treated rats

\begin{tabular}{lcc}
\hline & $\begin{array}{c}\text { Delta body } \\
\text { weight }(\mathrm{g})\end{array}$ & $\begin{array}{c}\text { Renal platinum } \\
(\mu \mathrm{g} \text { Pt/g tissue })\end{array}$ \\
\hline Control & $+12.5 \pm 1.6$ & $0.26 \pm 0.07$ \\
CFTR $_{\text {inh }}$-172 & $+13.3 \pm 2.4$ & $0.35 \pm 0.11$ \\
cisPt & $-8.4 \pm 2.6^{\star \star *}$ & $6.51 \pm 0.26^{\star \star \star}$ \\
cisPt + CFTR $_{\text {inh-172 }}$ & $+1.8 \pm 2.3^{\star * \# \#}$ & $7.20 \pm 0.39^{\star \star *}$
\end{tabular}

Data are expressed as the mean \pm S.E.M.. Each group was comprising 6-10 rats. ${ }^{\star *} P<0.01,{ }^{* \star \star} P<0.001$ versus control; ${ }^{\# \#} P<0.01$ versus cisplatin

WI, USA) on protein extracts ( $15 \mu \mathrm{g})$. The intensity of fluorescence was measured at excitation $360 \mathrm{~nm}$ and emission $460 \mathrm{~nm}$ with a Synergy HT Automated Microplate Reader (Bio-Tek Instruments, INC, Colmar, France), and caspase-3 activity was calculated as $\mathrm{pmol} / \mathrm{min} / \mathrm{mg}$ using AMC as a standard.

Intracellular GSH assays. The intracellular GSH cell contents were quantified using a GSH/GSSG Assay kit (Biovision, Mountain View, CA, USA). PCT cells or renal tissues were homogenized in an ice-cold GSH buffer, and proteins were removed by precipitation using perchloric acid and centrifugation. After neutralization of the supernatants using $\mathrm{KOH}$, the GSH contents were determined using an 0-phthalaldehyde (OPA) probe. In the assay, OPA reacts with GSH (not GSSG), generating fluorescence proportional to the GSH content. The fluorescence was measured at $420 \mathrm{~nm}$ (excitation $340 \mathrm{~nm}$ ) using a Synergy HT Automated Microplate Reader.

Measurement of ROS. ROS were measured by detecting the fluorescence intensity of carboxy- $\mathrm{H}_{2}$ DCFDA (5-(and-6)-carboxy-2', $7^{\prime}$-dichlorodihydrofluorescein diacetate), a ROS indicator that becomes spontaneously fluorescent when the acetate groups are removed by intracellular esterases and in the presence of intracellular ROS, most notably hydrogen peroxide. Briefly, confluent PCT cells were incubated in the presence of carboxy- $\mathrm{H}_{2}$ DCFDA $(5 \mu \mathrm{M})$ for 45 min and gently washed (HBSS + $10 \mathrm{mM}$ HEPES), and the fluorescence intensity was measured at $550 \mathrm{~nm}$ every 2 min using a microplate reader. At the end of a control period (20 min), cisplatin, $\mathrm{CFTR}_{\text {inh }}$-172 or tBHP (tert-butylhydroxyperoxide, $1 \mathrm{mM}$ ) was added to the medium, and the variation in fluorescence intensity was recorded for $120 \mathrm{~min}$. Slope variations of fluorescence intensity were calculated for each experimental condition for the first $60 \mathrm{~min}$ following the addition of the substances.

Platinum (Pt)-DNA adducts imaging and platinum content measurements. Immunofluorescence staining of Pt-DNA adducts was performed essentially as described by Liedert et al., ${ }^{21}$ with minor modifications. Briefly, PCT cells were co-incubated with or without CFTR inh $^{-172}(5 \mu \mathrm{M})$ and with cisplatin $(12.5 \mu \mathrm{g} / \mathrm{ml})$. After $4 \mathrm{~h}$ of incubation, the cisplatin was removed and cells were cultured for $20 \mathrm{~h}$. Cells were then gently trypsinized, washed with PBS, resuspended in an expander solution (PBS $+5 \%$ hydroxymethyl starch, HAES), spotted onto pre-coated slides (ImmunoSelect, Squarix, Marl, Germany), air-dried and fixed in methanol $\left(-20^{\circ} \mathrm{C}\right)$. Cells were then exposed to alkali denaturation $(60 \% \mathrm{NaOH} / \mathrm{NaCl} ; 40 \%$ methanol), to pepsin digestion $(60 \mu \mathrm{g} / \mathrm{ml}, 20 \mathrm{~min})$ and 

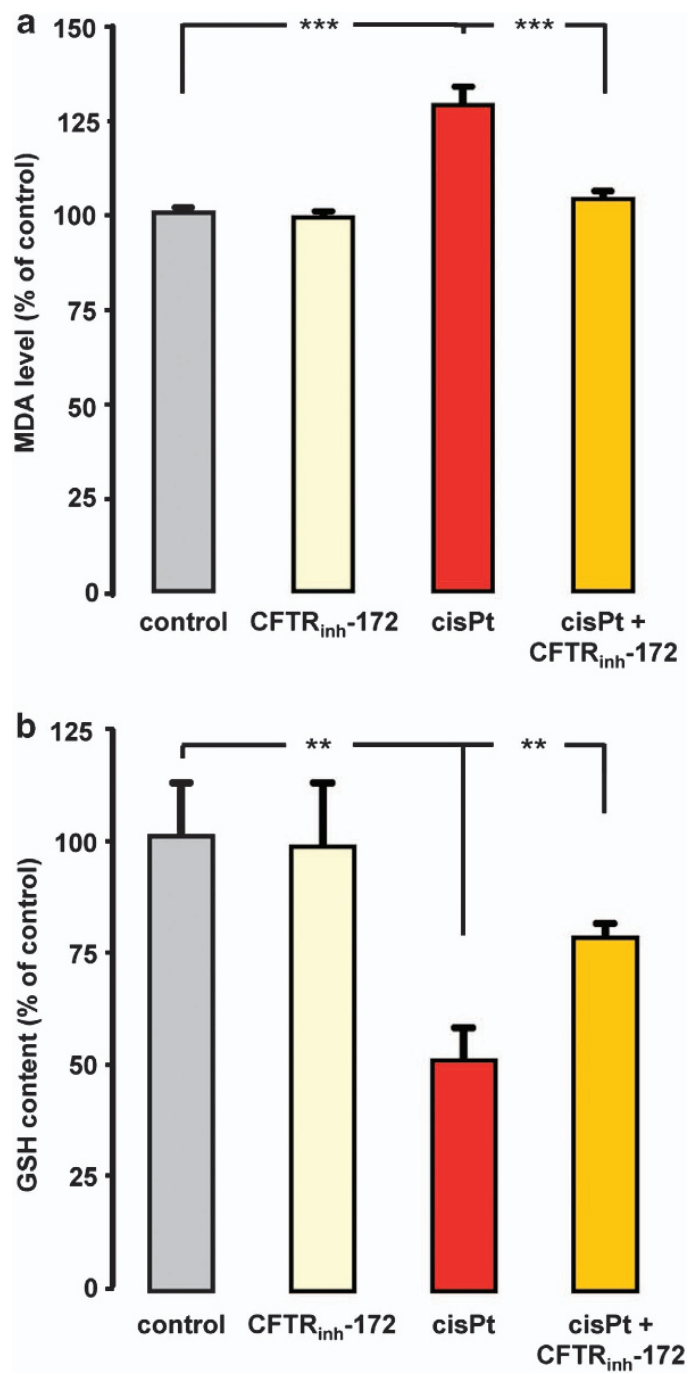

Figure 7 Effect of $\mathrm{CFTR}_{\text {inh }}-172$ treatment on oxidative stress markers in cisplatin-treated rat kidneys. (a) Lipid peroxidation products (malondialdehyde, MDA) and (b) GSH were measured in renal homogenates 2 days after a cisplatin injection $(5 \mathrm{mg} / \mathrm{kg})$ in control, $\mathrm{CFTR}_{\text {inh }}$-172-treated, cisplatin-treated and cisplatin + CFTR $_{\text {inh }}$-172-treated rats. Values are expressed as the means \pm S.E.M. of 3-5 rats per group. ${ }^{* *} P<0.01,{ }^{* *} P<0.001$

to a protein $\mathrm{K}$ treatment $(80 \mu \mathrm{g} / \mathrm{ml}, 20 \mathrm{~min})$; washed in PBS/glycine; and incubated in PBS $/ 5 \%$ milk powder for $1 \mathrm{~h}$. Cells were incubated overnight with the primary antibody specific for Pt-(GG) intrastrand adducts $(0.1 \mu \mathrm{g} / \mathrm{ml}$, Oncolyze, Essen, Germany), washed and exposed to the second fluorescent antibody (anti-rat IgG-FITC, 1/200, Abcam) before optical visualization (Zeiss Observer D1).

To estimate the cellular accumulation of platinum, confluent PCT cells were incubated for $4 \mathrm{~h}$ with cisplatin $(25 \mu \mathrm{g} / \mathrm{ml})$ in the absence or presence of CFTR inh $^{-172}$ $(5 \mu \mathrm{M})$ or at $4^{\circ} \mathrm{C}$. At the end of the incubation period, cells were rapidly washed three times $(1 \times$ in PBS, $0 \mathrm{mM} \mathrm{Ca}, 0 \mathrm{mM} \mathrm{Mg}, 1 \times$ in PBS-EGTA $1 \mathrm{mM}$, and finally $1 \times$ in PBS, $0 \mathrm{mM} \mathrm{Ca}, 0 \mathrm{mM} \mathrm{Mg})$ and lysed in a nitric acid solution $(6 \mathrm{~N}, 200 \mu \mathrm{l})$. To evaluate the platinum content in kidneys, weighed renal tissue samples were digested in concentrated nitric acid at a temperature of $40^{\circ} \mathrm{C}$ for $3 \mathrm{~h}$ under constant agitation. The platinum concentrations of digested samples were determined by atomic absorption spectrometry using a Zeeman furnace system (Solaar 969, Thermo Optek, Cambridge, UK).

Cisplatin antitumor activity in vitro. At $80 \%$ confluence, A549 cells were challenged with increasing doses of cisplatin $(0-40 \mu \mathrm{g} / \mathrm{ml})$ either alone or in combination with CFTR $_{\text {inh }}-172(5 \mu \mathrm{M})$. The following day, cell death was assessed by Hoechst 33342 (Invitrogen) and propidium iodide labeling and the morphology of the cell nuclei was observed with an EVOS fluorescence microscope at excitation wavelengths 350 and $536 \mathrm{~nm}$. Apoptotic/dead cells were identified by a nucleus with condensed chromatin or a total fragmented morphology into nuclear bodies. More than 500 cells in each sample were counted, and the percentage of apoptotic nuclei was determined.

Animals and treatments. The experiments were performed on adult female Wistar rats weighing 190-240 g (Janvier-Europe, France). The animals were fed a standard laboratory diet and had free access to water and food. All animal procedures were carried out in accordance with the French legislation for animal care and experimentation. The five groups of rats were defined as follows:

(1) control, receiving a single injection of $0.9 \%$ saline solution;

(2) CFTR $_{\text {inh }}-172$, receiving CFTR $_{\text {inh- }}-172$ (1 mg/kg, i.p.) and a single injection of $0.9 \%$ saline;

(3) cisplatin, receiving a single injection of cisplatin $(5 \mathrm{mg} / \mathrm{kg}$, i.p.);

(4) cisplatin + DMSO, receiving $0.5 \%$ DMSO, the vehicle for CFTR $_{\text {inh }}-172$ and a single injection of cisplatin $(5 \mathrm{mg} / \mathrm{kg}$, i.p.); and

(5) cisplatin + CFTR $_{\text {inh }}-172$ receiving CFTR $_{\text {inh }}-172$ (1 mg/kg, i.p.) and a single injection of cisplatin $(5 \mathrm{mg} / \mathrm{kg}$, i.p.).

The same volume was used for DMSO or CFTR $_{\text {inh }}-172$ and was injected the day before and $30 \mathrm{~min}$ prior to the unique injection of either saline solution or cisplatin. Cisplatin injections were realized in a volume equivalent to that of the saline solution. The animals were killed under anesthesia by intraperitoneal administration of pentobarbital sodium (Nembutal, $5 \mathrm{mg} / 100 \mathrm{~g}$, i.p.).

Renal function evaluation. Five days after the cisplatin injection, spontaneous voiding urine samples were collected, and blood samples were obtained via retro-orbital bleeding using heparinized capillary tubes. Creatinine and BUN were assessed in collected plasma samples with commercially available kits (Randox Laboratories, Crumlin, UK). Urinary levels of NGAL and NAG, indicators of tubular damage, were measured using an NGAL ELISA assay kit (Bioporto, Gentofte, Denmark) or with a colorimetric assay kit (Roche Applied Science, Mannheim, Germany), respectively. The absorbance was measured using a Microplate Reader. The urine osmolality was determined by freezing point depression (Roebling, Osmometer, Berlin, Germany).

Clearance experiments were also performed 5 days after the cisplatin injection. Anesthesia was induced by the injection of pentobarbital sodium (Nembutal, $5 \mathrm{mg} / 100 \mathrm{~g}$, i.p.). The animals were then placed on a heated table to maintain their body temperature at $37^{\circ} \mathrm{C}$. One catheter (PE-20) was inserted into the right jugular vein for the perfusion of experimental solutions, and another catheter (PE-10) was inserted into the left ureter for urine collection. A PE-50 catheter was inserted into the right femoral artery for blood sampling and arterial blood pressure recording (Research BP Transducer, Harvard Apparatus). The clearance experiments were carried out in rats intravenously infused with a $0.9 \% \mathrm{NaCl}$ solution at a rate of $20 \mu \mathrm{l} / \mathrm{min}$. FITC-inulin (6 $\mathrm{mg} / \mathrm{ml} 0.9 \% \mathrm{NaCl}$ solution) was used to measure the GFR. In all experiments, a loading dose of FITC-inulin $(2.5 \mathrm{mg} / 200 \mathrm{~g})$ was administered intravenously. After a 40-min equilibration period, a urine sample from the left kidney was collected in a 30-min experimental period. A midpoint blood sample was drawn.

The GFR was evaluated based on inulin clearance. FITC-inulin levels in the urine and plasma samples were measured with a spectrofluorimeter. The GFR was calculated as the ratio of urine to plasma inulin concentration multiplied by the urine flow rate. To assess the proximal tubular function, $\mathrm{Na}^{+}$concentrations were determined by flame atomic absorption spectrometry (Thermo Solaar AA series S2, Cambridge, UK), and glucose concentrations were measured by the hexokinase method using a commercial Randox kit (Randox Laboratories). Fractional excretions were calculated according to the following equation: fractional excretion (compound $Z)(\%)=($ compound $Z$ clearance/inulin clearance $) \times 100$, where compound $Z=$ sodium or glucose.

Measurements of lipid peroxidation in rat kidney. Assays were performed in renal tissue from rats killed 2 days after a cisplatin injection. Lipid peroxidation products (malondialdehyde, MDA) were assayed with a Lipid Peroxidation Colorimetric assay kit (Oxford Biomedical Research, Oxford, MI, USA) containing a chromogenic agent ( $\mathrm{N}$-methyl-phenylindole) that reacts with MDA at $45^{\circ} \mathrm{C}$, yielding a stable chromophore with a maximum absorbance at $586 \mathrm{~nm}$. 
Statistical analysis. Quantitative data are expressed as the means \pm S.E.M. Student's $t$-test and a one-way ANOVA were used to compare the means of two groups and of multiple treatment groups, respectively.

\section{Conflict of Interest}

The authors declare no conflict of interest.

Acknowledgements. We thank Professor F Lang for critically reading the manuscript. This work was supported by SATT SUD-EST (previously ValorPACA) and the Centre National de la Recherche Scientifique (CNRS).

1. Wang D, Lippard SJ. Cellular processing of platinum anticancer drugs. Nat Rev Drug Discov 2005; 4: 307-320.

2. Launay-Vacher V, Rey JB, Isnard-Bagnis C, Deray G, Daouphars M. Prevention of cisplatin nephrotoxicity: state of the art and recommendations from the European Society of Clinical Pharmacy Special Interest Group on Cancer Care. Cancer Chemother Pharmacol 2008; 61: 903-909.

3. Pabla N, Dong Z. Cisplatin nephrotoxicity: mechanisms and renoprotective strategies. Kidney Int 2008; 73: 994-1007.

4. Sanchez-Gonzalez PD, Lopez-Hernandez FJ, Lopez-Novoa JM, Morales Al. An integrative view of the pathophysiological events leading to cisplatin nephrotoxicity. Crit Rev Toxicol 2011; 41: 803-821.

5. Ciarimboli G, Ludwig T, Lang D, Pavenstadt H, Koepsell H, Piechota HJ et al. Cisplatin nephrotoxicity is critically mediated via the human organic cation transporter 2. Am J Pathol 2005; 167: 1477-1484.

6. Pabla N, Murphy RF, Liu K, Dong Z. The copper transporter Ctr1 contributes to cisplatin uptake by renal tubular cells during cisplatin nephrotoxicity. Am J Physiol Renal Physiol 2009; 296: F505-F511.

7. Ciarimboli G, Deuster D, Knief A, Sperling M, Holtkamp M, Edemir B et al. Organic cation transporter 2 mediates cisplatin-induced oto- and nephrotoxicity and is a target for protective interventions. Am J Pathol 2010; 176: 1169-1180.

8. Lieberthal W, Triaca V, Levine J. Mechanisms of death induced by cisplatin in proximal tubular epithelial cells: apoptosis vs. necrosis. Am J Physiol 1996; 270(4 Pt 2): F700-F708.

9. Hanigan MH, Devarajan P. Cisplatin nephrotoxicity: molecular mechanisms. Cancer Ther 2003; 1 : 47-61.

10. Santos NA, Bezerra CS, Martins NM, Curti C, Bianchi ML, Santos AC. Hydroxyl radical scavenger ameliorates cisplatin-induced nephrotoxicity by preventing oxidative stress, redox state unbalance, impairment of energetic metabolism and apoptosis in rat kidney mitochondria. Cancer Chemother Pharmacol 2008; 61: 145-155.

11. Do Amaral CL, Francescato HD, Coimbra TM, Costa RS, Darin JD, Antunes LM et al. Resveratrol attenuates cisplatin-induced nephrotoxicity in rats. Arch Toxicol 2008; 82: 363-370.

12. Saleh S, Ain-Shoka AA, El-Demerdash E, Khalef MM. Protective effects of the angiotensin II receptor blocker losartan on cisplatin-induced kidney injury. Chemotherapy 2009; 55: 399-406.

13. Chirino YI, Pedraza-Chaverri J. Role of oxidative and nitrosative stress in cisplatin-induced nephrotoxicity. Exp Toxicol Pathol 2009; 61: 223-242.

14. Jouret F, Bernard A, Hermans C, Dom G, Terryn S, Leal T et al. Cystic fibrosis is associated with a defect in apical receptor-mediated endocytosis in mouse and human kidney. $\mathrm{J} \mathrm{Am}$ Soc Nephrol 2007; 18: 707-718.

15. Barriere H, Belfodil R, Rubera I, Tauc M, Poujeol C, Bidet M et al. CFTR null mutation altered CAMP-sensitive and swelling-activated $\mathrm{Cl}$ - currents in primary cultures of mouse nephron. Am J Physiol Renal Physiol 2003; 284: F796-F811.

16. Duranton C, Rubera I, Cougnon M, Melis N, Chargui A, Mograbi B et al. CFTR is involved in the fine tuning of intracellular redox status: physiological implications in cystic fibrosis. $A m \mathrm{~J}$ Pathol 2012; 181: 1367-1377.

17. I'Hoste S, Chargui A, Belfodil R, Corcelle E, Duranton C, Rubera I et al. CFTR mediates apoptotic volume decrease and cell death by controlling glutathione efflux and ROS production in cultured mice proximal tubules. Am J Physiol Renal Physiol 2010; 298: F435-F453.
18. L'Hoste S, Chargui A, Belfodil R, Duranton C, Rubera I, Mograbi B et al. CFTR mediates cadmium-induced apoptosis through modulation of ROS level in mouse proximal tubule cells. Free Radic Biol Med 2009; 46: 1017-1031.

19. Ma T, Thiagarajah JR, Yang H, Sonawane ND, Folli C, Galietta LJ et al. Thiazolidinone CFTR inhibitor identified by high-throughput screening blocks cholera toxin-induced intestinal fluid secretion. J Clin Invest 2002; 110: 1651-1658.

20. Barriere H, Poujeol C, Tauc M, Blasi JM, Counillon L, Poujeol P. CFTR modulates programmed cell death by decreasing intracellular $\mathrm{pH}$ in Chinese hamster lung fibroblasts. Am J Physiol Cell Physiol 2001; 281: C810-C824.

21. Liedert B, Pluim D, Schellens J, Thomale J. Adduct-specific monoclonal antibodies for the measurement of cisplatin-induced DNA lesions in individual cell nuclei. Nucleic Acids Res 2006; 34: e47.

22. Bazzi C, Petrini C, Rizza V, Arrigo G, Napodano P, Paparella M et al. Urinary N-acetylbeta-glucosaminidase excretion is a marker of tubular cell dysfunction and a predictor of outcome in primary glomerulonephritis. Nephrol Dial Transplant 2002; 17: 1890-1896.

23. Mishra J, Mori K, Ma Q, Kelly C, Barasch J, Devarajan P. Neutrophil gelatinase-associated lipocalin: a novel early urinary biomarker for cisplatin nephrotoxicity. Am J Nephrol 2004; 24: $307-315$.

24. Arany I, Megyesi JK, Kaneto H, Price PM, Safirstein RL. Cisplatin-induced cell death is EGFR/src/ERK signaling dependent in mouse proximal tubule cells. Am J Physiol Renal Physiol 2004; 287: F543-F549.

25. Jiang $M$, Wei $Q$, Pabla N, Dong G, Wang $C Y$, Yang $T$ et al. Effects of hydroxyl radical scavenging on cisplatin-induced p53 activation, tubular cell apoptosis and nephrotoxicity. Biochem Pharmacol 2007; 73: 1499-1510.

26. Kim J, Long KE, Tang K, Padanilam BJ. Poly(ADP-ribose) polymerase 1 activation is required for cisplatin nephrotoxicity. Kidney Int 2012; 82: 193-203.

27. Pabla N, Dong G, Jiang M, Huang S, Kumar MV, Messing RO et al. Inhibition of PKCdelta reduces cisplatin-induced nephrotoxicity without blocking chemotherapeutic efficacy in mouse models of cancer. J Clin Invest 2011; 121: 2709-2722.

28. Seeger MA, van Veen HW. Molecular basis of multidrug transport by $A B C$ transporters. Biochim Biophys Acta 2009; 1794: 725-737.

29. Katsuda H, Yamashita M, Katsura H, Yu J, Waki Y, Nagata N et al. Protecting cisplatininduced nephrotoxicity with cimetidine does not affect antitumor activity. Biol Pharm Bull 2010; 33: 1867-1871.

30. Sonawane ND, Muanprasat C, Nagatani R Jr., Song Y, Verkman AS. In vivo pharmacology and antidiarrheal efficacy of a thiazolidinone CFTR inhibitor in rodents. J Pharm Sci 2005; 94: $134-143$

31. Thiagarajah JR, Broadbent T, Hsieh E, Verkman AS. Prevention of toxin-induced intestinal ion and fluid secretion by a small-molecule CFTR inhibitor. Gastroenterology 2004; 126: 511-519.

32. Salinas DB, Pedemonte N, Muanprasat C, Finkbeiner WF, Nielson DW, Verkman AS. CFTR involvement in nasal potential differences in mice and pigs studied using a thiazolidinone CFTR inhibitor. Am J Physiol Lung Cell Mol Physiol 2004; 287: L936-L943.

33. Akiba $Y$, Jung M, Ouk S, Kaunitz JD. A novel small molecule CFTR inhibitor attenuates HCO3- secretion and duodenal ulcer formation in rats. Am J Physiol Gastrointest Liver Physiol 2005; 289: G753-G759.

34. Snyder DS, Tradtrantip L, Yao C, Kurth MJ, Verkman AS. Potent, metabolically stable benzopyrimido-pyrrolo-oxazine-dione (BPO) CFTR inhibitors for polycystic kidney disease. J Med Chem 2011; 54: 5468-5477.

35. Humanes B, Lazaro A, Camano S, Moreno-Gordaliza E, Lazaro JA, Blanco-Codesido M et al. Cilastatin protects against cisplatin-induced nephrotoxicity without compromising its anticancer efficiency in rats. Kidney Int 2012; 82: 652-663.

36. Sengupta P, Basu S, Soni S, Pandey A, Roy B, Oh MS et al. Cholesterol-tethered platinum Il-based supramolecular nanoparticle increases antitumor efficacy and reduces nephrotoxicity. Proc Natl Acad Sci USA 2012; 109: 11294-11299.

37. Lacroix J, Poet M, Maehrel C, Counillon L. A mechanism for the activation of the $\mathrm{Na} / \mathrm{H}$ exchanger NHE-1 by cytoplasmic acidification and mitogens. EMBO Rep 2004; 5: 91-96.

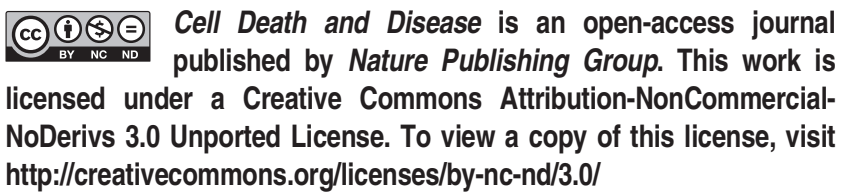

